$$
\text { rief }
$$

OPEN ACCESS

Citation: P. Huion, M. Hakan Ayçiçek (2021) Not All Migrant Men Embrace Toxic Masculinity, Do They?. Rief 18, 2: pp. 41-50. doi: https://doi.org/ 10.36253/rief10521.

Copyright: @ 2021 P. Huion, M. Hakan Ayçiçek. This is an open access, peer-reviewed article published by Firenze University Press (https://oaj.fupress.net/ index.php/rief) and distributed under the terms of the Creative Commons Attribution License, which permits unrestricted use, distribution, and reproduction in any medium, provided the original author and source are credited.

Data Availability Statement: All relevant data are within the paper and its Supporting Information files.

Competing Interests: The Author(s) declare(s) no conflict of interest.
Firenze University Press

https://oaj.fupress.net/index.php/rief

\section{Not All Migrant Men Embrace Toxic Masculinity, Do They?}

\author{
Patricia Huion ${ }^{1}$, Muhammet Hakan Ayçiçek ${ }^{2}$
}

Abstract

Gender identities and roles have changed over time and have reached their present meanings. In addition, the expectations and acceptance of different cultures have caused these roles to show various developments. Finally, the increase in immigration to Europe has forced these young people who grew up in other cultures and their families to learn to live in a new culture and mandatory adaptation of two cultures. The biggest problem with mixing in a new culture was that the male trait, defined as toxic masculinity and taught as a power in eastern cultures, was not accepted in this new culture. Toxic masculinity is a man proving his existence to his gender, other genders, and entire social environment through anger, destructiveness, and pressure. "CommUnity" Project aims to bring together the young people of these different cultures with art-based design thinking activities. Those will help them get to know, understand, and adapt to each other in a peaceful environment where they can discuss the problem solutions openly and do art activities together. The main expectation is that the young people who have changed with these works will influence their environment and lead to a shared society that does not experience unnecessary violence and radicalism and lives in harmony.

Keywords: genders, toxic masculinity, refugees, migration, arts-based activities.

Abstract

Le identità e i ruoli di genere sono cambiati nel tempo e hanno raggiunto i loro significati attuali. Inoltre, le aspettative e l'accettazione delle diverse culture hanno fatto sì che questi ruoli mostrassero vari sviluppi. Infine, l'aumento dell'immigrazione in Europa ha costretto questi giovani cresciuti in altre culture e le loro famiglie a imparare a vivere in una nuova cultura e all'adattamento obbligatorio di due culture. Il problema più grande con la mescolanza in una nuova cultura era che il tratto maschile, definito come mascolinità tossica e insegnato come un potere nelle culture orientali, non era accettato in questa nuova cultura. La mascolinità tossica è un uomo che dimostra la sua esistenza al suo genere, ad altri generi e all'intero ambiente sociale attraverso la rabbia,

${ }^{1}$ Senior Researcher - UC Leuven-Limburg (UCLL) Hogeschool, Research and Expertise, Belgium.

${ }^{2}$ Researcher - UC Leuven-Limburg (UCLL) Hogeschool, Research and Expertise, Belgium. 
la distruttività e la pressione. Il Progetto "CommUnity" mira a riunire i giovani di queste diverse culture con attività di design thinking basate sull'arte. Questi li aiuteranno a conoscersi, capirsi e adattarsi l'un l'altro in un ambiente pacifico dove possono discutere apertamente le soluzioni dei problemi e fare attività artistiche insieme. L'aspettativa principale è che i giovani che sono cambiati con queste opere influenzino il loro ambiente e portino a una società condivisa che non sperimenti violenza e radicalismo inutili e viva in armonia.

Parole chiave: generi, mascolinità tossica, rifugiati, migrazione, attività artistiche.

In the "CommUnity" Project (Horizon 2020), two academic partners and eight grass-root change agents from different European countries work together to design prevention trajectories through arts-based, community-building activities. The target co-creators are young people and their fathers, mothers, community leaders. Throughout the Project, there is a gender-based focus separating men and women for some activities. Through design thinking, the consortium discovered that confusion about the core concepts, even about radicalisation, causes passivity or biased prevention strategies.

In this paper, we therefore explore one of these ambiguous concepts: the migrant man. We differentiate between different male identities, zoom in on toxic masculinity and reflect on choices men are confronted with in their integration process. Thus, we create a disentangled frame for partners to start their design thinking with.

\section{Gender Roles Past and Present}

Gender roles, masculinity and femininity are universal concepts which have been a part of our lives ever since human beings started living together in communities. The perception and acceptance of these roles vary significantly between regions and cultures and these roles are also constantly altering all around the world due to changing living conditions. In addition to all these, many new gender identities have been added to them over time and they all need to understand and accept each other to live in harmony.

Ever since the creation of human beings they have been distinguished as men and women. Since hunter and gatherer societies men and women have taken different roles and responsibilities to sustain a life standard and to maintain order within society. Between the 1820 s to 1860 s, the concepts of "true woman" and "true man" were structured and male and female roles were defined by these (Katz, 1983, 1995). The "true woman" was expected to be pious, pure, submissive, and domestic whereas the "true man" was expected to be devoted to hard work and material success, assertive, humanitarian, have a proper sex life and be an affectionate patriarchal ruler (Katz, 1983).

Nowadays, there are many different gender identities in addition to man and woman, including transgender, gender neutral, non-binary, agender, pangender, genderqueer, two-spirit, third gender, and all, none, or a combination of these. The definition of the distinction between heterosexuality and homosexuality started between 1880-1920: heterosexuality was considered as normal and linked to masculinity whereas homosexuality was accepted as abnormal and linked to femininity (Nelson, 2019). The description of "true man" and masculinity (heterosexuality) given above was valid until around 1980s but recently masculinity has been defined with attributes like misogyny and homophobia in addition to the above given ones (Mahalik, Good et al., 2003). These concepts play a significant role in understanding masculinity today. 


\section{Masculinities}

There are lots of definitions used for masculinity, but it is generally associated with men and can be defined with a set of characteristics, behaviors, and social roles (Kirby, 2019). Traditional masculinity has frequently been understood as unemotional, emotionally impaired, or somewhat stoic (Sculos, 2017). The definition offered by Hooks (2004), reveals an image of masculinity from a male point of view.

The first act of violence that patriarchy demands of males is not violence toward women. Instead, patriarchy demands of all males that they engage in acts of psychic self-mutilation, that they kill off the emotional parts of themselves. If an individual is not successful in emotionally crippling himself, he can count on patriarchal men to enact rituals of power that will assault his self-esteem (Reeser, Gottzen, 2018, p. 6).

Emotion suppression has been emphasized by different researchers in different wordings. Such as men learning to perceive emotions as signs of weakness and as a threat to their masculinity, try to prevent others from seeing through them and keep their fears secluded (Seidler, 1989; Kimmel, 1994). In western point of view suppressing emotions is mostly emphasized whereas in eastern point of view being the ruler, provider, and controller of the community and of women are more dominant (El Feki, Heilman et al., 2017; Kimmel, 1994; Marcus, 2019; Sculos, 2017; Seidler, 1989).

The most crucial part regarding masculinity is that the gender socialization begins at an early age and continues throughout adulthood and an individual shall conform to the gender roles he is assigned if he does not want to be judged harshly and treated as if he is abnormal (Nelson, 2019). The effort to define masculinity from different aspects brings along the necessity of making multiple masculinity descriptions. Although not universally agreed there are some general definitions of masculinity types. One of them is "traditional masculinity" which describes the male as a provider and protector of the family, ready to fight for his values and people he cares about. In addition, while taking care of all these issues he keeps his problems to himself. The second one is "positive masculinity" which generally describes the transformed male attitudes into socially useful behaviors like policemen, fire fighters. The last one is "hegemonic masculinity" which is sometimes named as "toxic masculinity". Although these two definitions cover the different aspects of masculinity sometimes one is being used in the place of the other (Barry, Walker, et al., 2020). In her work named Masculinities (1995), Connell also highlighted that the gender norms have a negative impact on emotional lives of men (Dognin, Chen, 2018). Connell puts forth a new concept which is called "hegemonic masculinity" where she defines masculinity as a strive for dominance which includes dominance over women (Connell, 1987; Waling, 2019a,b). She conducted a research among Australian high schools in early 1980s investigating the social inequity. The results showed that there was a hierarchical structure between boys, which was rooted in how actively they projected their gender identity and masculinity (Connell, 1983; Kessler, Ashenden et al., 1982). Connell claims that men can choose to strictly attach, deny, or try to resist masculinity (Connell, 1992). According to this choice men access different levels of power and status in society. Those who attach and engage successfully maintain "hegemonic masculinity" (Connell, 1992; Waling, 2019a,b).

Hegemonic masculinity is described generally as adherence to strict gender roles and power structures which are built upon the domination of women, devaluation of feminine attributes, establishing a hierarchy of intermale dominance and stigmatization of homosexuality. It also includes a ruthless and highly competitive nature and unwillingness to express emotions or any form of behavior that could be constructed as weak or vulnerable (Brittan, 1989; Kupers, 2005). 
But in addition to this, hegemonic masculinity also covers a man's healthy competitiveness, being a reliable provider or being good at his career and as there is nothing bad in a man's pride, in his ability to win at sports, to succeed at work and provide for his family, a need for a subtitle arose to define the negative aspects of masculinity and "toxic masculinity" was preferred.

\section{Toxic Masculinity: Definition and How It Is Created}

This new definition is mainly used to define the destructive manners like socially dominant, misogynistic, violent, and homophobic behaviors where men do not just victimize women and children but also one another (Borinca, Iacoviello et al., 2020; Christensen, Henderson et al., 2019). Connell and others theorized that the problem with masculinity turning from a healthy one to a toxic one comes from setting unattainable standards regarding social respect, physical strength, and sexual potency. When boys and men fall short in achieving those standards, they feel insecure and anxious and this might prompt them to use force to feel and be dominant and in control. In this scenario the violence does not arise from something bad or toxic but only from wrongly interpreted nature of masculinity itself (Salter, 2019).

Not only wrongly interpreted forms of masculinity but also having to perform counter-stereotypical gender behavior prove problematic (Borinca, Iacoviello et al., 2020). In the related research three experiments were done. The first one, was comparing men's and women's discomfort while imagining counter-stereotypical behaviors, the second one was comparing men from two culturally different samples (US and Kosovo men) and the aim was to show perceived changes in men's gender norms according to different cultures and the third one was to find the main dependent variable of the effect of gender traits (Ibidem). This discomfort causes them to show defensive reactions and aggressive behaviors to prove their status. It appears that much discomfort and reaction come from the anxiety of being classified as gay (Ibidem). Lack of performing these stereotype behaviors caused them to feel devaluated or ashamed in front of their peers (Nhan, 2018). However, research showed that men who live through the traditional masculinity properties at less dominant levels felt less discomfort when they imagined themselves performing counter-stereotypical behaviors such as talking about their emotions, shopping for clothes, designing a living room, etc. (Borinca, Iacoviello et al., 2020).

The masculinity crisis deeply affects young men who are in the critical development period and in search of an identity, especially as boys are more quickly affected by the negative attributes than girls (Sculos, 2017). Boys learn how to be masculine at home through their parents, family, and social circles. In a developmental perspective a repeated interaction with people demonstrating certain values and attitudes causes the boy to learn and absorb those patterns (Nhan, 2018).

They also learn toxic masculinity through the level of violence and aggression at home. Indeed, teaching young boys to be super aggressive and that fighting is a way to show dominance and masculinity promotes toxic masculinity. As fighting is the only option to win, they can play rough, break the rules, and can try to win at all costs (Garbarino, 2000).

"Toxic masculinity" is not only something that some men use to harm people around them. It can be also harmful to the men themselves as it often harms the man by injuring relationships, increasing isolation, and suppressing pain and suffering (Christensen, Henderson et al., 2019). They generally deny their health problems and do not seek for help as a health problem makes them vulnerable and is a degradation of self-image. Also, overindulgence in unhealthy foods, risk taking behaviors, smoking and excessive alcohol or drug consumption are accepted by them as societies' expectation from their role (Kirby, 2019). In addition, their suppressing emotions leads to mental health issues such as depression and anxiety (Waling, 2019a,b). 
There is another side of being "toxic" as they are considered to be dangerous this might cause people to be socially distanced from them (Tajfel, Turner, 1979). This social isolation can worsen the mental problems, may reinforce hegemonic traits but much worse it increases the risk of suicide (Iwamoto, Brady, et al., 2018). According to various research done adherence to rigid masculine norms may lead to:

- Worsening of depression and anxiety and overall psychological distress;

- abuse of substances;

- cardiovascular and metabolic diseases;

- $\quad$ issues with interpersonal intimacy;

- discouragement in seeking help;

- homophobia (Chatmon, 2020, passim).

To change the general effect of masculinity traits on a developing child some measures can be taken. First correcting aggressive and violent behaviors with an effective, supportive, and appropriate discipline and interacting with positive role models can help to reduce the risk factors (Nelson, 2019). Currently, young boys lack the feeling part of morality due to being taught to close off and lock away their emotions in general. This prevents them from learning empathy, and this is not only a problem of a family, relationship, and community it is a problem concerning all society (Garbarino, 2000). Also combining traditional masculine and feminine traits, attributes, and behaviors while raising young boys and helping them to understand this combination is normal may cause great difference in their perception of masculinity (Garbarino, 2000; Nelson, 2019).

In addition to all these, masculinities ascribe blame to sexually assaulted men and this causes victims to keep silent and not to seek for support. It is difficult to accept victimhood by men according to the accepted norms of masculinity and sexual assault is the antithesis of these norms. In different research men described the experience of male domination and control as intimidating, disturbing and threatening and being afraid that they cannot be considered as men anymore. The difference between women and men when sexual assault is considered is that women are accepted to be victims as men are stronger than them but when a man is sexually assaulted, he is expected to resist the assaulter. All these prevent the sexually assaulted men from seeking help and much worse prevent them even from reporting the victimization (Nelson, 2019).

\section{Gender Roles and Migration}

While gender fluidity may cause conflict, chaos and confusion for some natives in receiving countries, it certainly results in collisions about gender roles, norms and traits within different cultures. The immigrants who are trying to get along with a complete change in their lifestyle, living and working conditions must also fight, learn, and comply with these cultural differences affecting their life at home, at work and in public. The young generations are the ones who are most affected by these changes, as they have to fit in this new culture at the critical age where their social character, perspective of life and family are just developing while they have no chance of rejecting or even arguing about the cultural beliefs of the family they belong to.

Even though both migrant men and women have problems with fitting into the new countries and cultures as they hang on to the firm beliefs about their culture and gender relations with them, men are exposed to greater intolerance, violence, and discrimination in the new country than women. The reason of this is, that women are initially left at home and in their closed interaction circle with other immigrants and have more time to fit in the new culture 
with less pressure. However, this new world men are exposed to sometimes erodes and sometimes fortifies their sense of masculinity. In this new country the work opportunities and their standard of living are not always the same as they had in their own country. This inability to be a main provider of the household causes stress and a feeling of being "lessened" for migrant men as they generally experience their masculinity and gendered sense of self by this power.

Those difficulties, uncertainties, and discrimination that they suffer from may cause the migrant men to try even harder to live and act "like a man" resulting in signs of an «exaggerated masculinity» (Donaldson, Howson, 2009, passim).

\section{The Dangerous Migrant Man}

In migrant receiving countries there is a general belief that gender-based violence is being "imported" into their country by immigrants (Kurassinska, 2019).

The International men and gender equality survey (IMAGES)- MENA is the first and the most extensive study held till now in the Middle East and North Africa (MENA) regions (El Feki, Heilman et al., 2017). Four countries that are included in the first study of MENA are Egypt, Lebanon, Morocco, and Palestine.

The aim of this study was to better understand how men see themselves as sons, husbands, and fathers in different roles of life, such as at home, at work and in public in those areas. In addition, how they evaluate gender equality and what are the attitudes and the actions they have toward gender equality (Ibidem). In all four countries, half to three-quarters of the men reported having experienced physical violence in the homes they grew up in, and two-thirds or more reported having experienced physical violence by teachers or peers in school. The violence men and women experienced as children turns into violence against their own children. Violence against children is also gendered: in most countries, fathers tend to use more physical punishment against sons. More than 60 per cent of men and almost half of women believe that wives should tolerate violence to keep the family together. More than half of men reported ever having sexually harassed a woman or girl, and more than 60 per cent of women reported such unwanted attentions. More women than men blamed the victim's appearance for provoking harassment. Most men and even many women support traditional attitudes about masculinity and femininity which perpetuate violence against women and the belief that the women and the girls in the household should be monitored and controlled by the man who is responsible for them (El Feki, Heilman et al., 2017). Unfortunately, most men and women learned gender-specific behaviors starting from childhood, sometimes also under the effect of religious conservatism which is extremely hard to change.

Muslim men who migrated from the MENA Region (Middle East and North Africa region) to Europe, the United States, and elsewhere, are seen as violent and dangerous (Ibidem). Especially young men are often defined as 'dangerous' and tied to discussions on terrorism, youth riots and immigration (Herz, 2017) and the idea that refugee men need to be educated to change their views on sexuality and gender is strongly represented in "Western" politics and policies (Eriksson, Stern, 2013; Olivius, 2016; Stretmo, 2014). In general, the migrants fear losing their privilege of being a "real man", a dominant leader, the provider of the family, a protective husband, and a father while fitting in the new culture. When they think that they cannot meet the ideals of masculinity, they feel they have lost their privileged position of power which advocates domination, rejection of feminine and homosexual identity and denial of all his weaknesses. Sometimes this pressure causes them to be violent to feel the power they are afraid to lose (Lenders, 2018). 
Unfortunately, in the new culture they try to fit in, young people are constantly confronted with "the image of how a man should be" through social media, advertisements, and pop culture. In between this social pressure and the cultural doctrines of their own, a sizeable minority have been coming closer to the idea of supporting the changes in women's equality and empowerment and not confining women to conventional roles. Those agree that women should be protected from men's violence, they support women's presence in business and having a career.

In addition, a great majority of men claim they would accept a woman as a boss and are willing to work in gender-integrated workplaces in theory and as long as they are still the breadwinner and the women are still the caregiver at home (El Feki, Heilman et al., 2017).

\section{Integration and Toxic Masculinity}

Another Research project involving 20 young immigrant males and females who arrived in Sweden was held in 2017 (Marcus, 2019). The main interest of the research was to reflect how young people fit in this new life and create a meaning in their everyday life (Ibidem).

One of those young males was Halid, who was 18 years old at the time the article was published and came to Sweden from Iran. His brother, mother and other siblings joined him later. Halid being the oldest son, explained himself and his position in the family as follows: he should not cry in front of his brothers, he did his crying in his room as he should be strong and is not allowed to show fear or sadness (Ibidem).

Another one was Tiego from Syria. He was 19 years old and he was happy when his family was able to come to Sweden. However, "now he had to get permission for whatever he does" from his father. He was having a rough time making his father understand how life is in Sweden. His father preferred to discuss and decide any issue with his friends from his homeland living also in Sweden and was trying to make Tiego do what they decided. The reason for this was his father believed that men had no rights in Sweden and was extremely afraid that his son was getting under the influence of this idea (Ibidem).

However difficult these intergenerational, gender and cultural differences are to comply with, they are not toxic. They are just differences and the people involved may understand them and adopt this new culture over time. But stress and the feeling of losing power can change these beliefs into toxic and violent behaviors.

\section{Interfering with Toxic Masculinity}

According to different research it has been seen that to some extend men and women are both disturbed with the idea of toxic masculinity, so researchers have begun to work on different methods to reduce the aggression and levels of toxic masculinity. They have seen that using language such as 'healthy' instead of 'toxic' can be a significant first step in supporting boys and men to embrace and engage with emotion and vulnerability.

These different methods include therapy, intervention programs, proper education programs, creating more positive family environments, and strong and positive community environments. All of these can be applied to migrant boys and their families with properly arranged programs. Therapy can assist boys through discussing their lives, own victimization, and personal experiences in a safe environment to promote healing from trauma and proper mental and emotional health development and help them to create safe spaces to engage with their vulnerability. A proper education program assists boys with their mental development and creates a safe space away from dysfunctional and harmful homes. Teaching parents how to create 
positive family environments even if a parent is missing promotes stability and benefits mental and emotional development. A strong positive community assists family in teaching young boys right from wrong, builds a sense of community, promotes proper mental and emotional development (Garbarino, 2000).

For teaching the boys to feel and to express their feelings production of music, art or literature will be immensely helpful. According to a study done with trauma victims most of the study participants suggested that artistic expression as a form of self-help has worked on them to understand, process, and articulate their experience and to heal. Several of the study participants who express themselves artistically described this as a sphere in which they are free to be emotional and to resist injustice and unequal power relations. This is consistent with other findings which suggest that the renegotiation of masculinity is an important process for victims in healing from a traumatic past (Crete, Singh, 2015; Forde, Duvvory, 2017; Kia-Keating, Grossman et al., 2005).

\section{Conclusion}

One important issue that should not be ignored is that gender-based violence is mostly affected by violence supporting attitudes in the family and the community and highly violent childhoods and the prevalence of this issue is remarkably close to each other in all cultures. When migrant men are considered, it is not only the effect of violence they are exposed to but also the cultural pressures and the thought of having the privileges of being a man affect the migrant boys' idea regarding masculinity and make them feel obliged to not to show their emotions and be strong in all circumstances. Despite all those effects not all migrant men embrace toxic masculinity. Men can avoid the toxic nature of masculinity if they engage in the right precautions but can only do so if they are raised by their family and the society with the idea that being respectful, emphatic, caring, accepting and kind to all human beings is a much bigger strength then violating, despising, and dominating them. This is exactly what should be taught to the migrant boys and their families with supporting programs.

Because of the new world and the culture, they are exposed to, some of them do not feel comfortable with choosing healthy masculinity without any need of interference and for the others this choice can be facilitated in "CommUnity" and its arts-based activities.

Finally, there can still some men who still prefer a radical choice: toxic masculinity, not respecting anybody including themselves and those are the main reason of "CommUnity" to open up the debate about masculinities and especially the toxic masculinity, as this last one is a direct link to violent radicalism.

While finishing, the psychological pressure of being a "toxic" masculine and even sometimes a "hegemonic" masculine with restrictive beliefs regarding emotions can be described by the verses from Hyperion (Longfellow, 1839): «Believe me, every heart has its secret sorrows, which the world knows not, and oftentimes we call a man cold, when he is only sad» (ivi, p. 96).

\section{References}

Barry J., Walker R., Liddon L., Seager M. (2020): Reactions to Contemporary Narratives about Masculinity: A Pilot Study. Psychreg Journal of Psychology, 4(2), pp. 8-21.

Borinca I., Iacoviello V., Valsecchi G. (2020): Men's Discomfort and Anticipated Sexual Misclassification Due to Counter-Stereotypical Behaviors: The Interplay between Traditional Masculinity Norms and Perceived Men's Femininization. Sex Roles, n.d. (https://doi.org/10.1007/s11199-020-012105; last access: 10.11.21). 
Brittan A. (1989): Masculinity and Power. Hoboken (NY): Basil Blackwell.

Chatmon B.N. (2020): Males and Mental Health Stigma. American Journal of Men's Health, 14(4) (https://doi.org/10.1177/1557988320949322; last access: 10.11.21).

Chen C.K., Dognin J. (2017): Addressing the Influence of Hegemonic Masculinity on Veterans through Brief Dynamic Interpersonal Therapy. Psychology of Men \& Masculinity, n. 18, pp. 238-242.

Christensen J.K., Henderson J.D., Dorn-Medeiros C.M., Lertora I. (2019): Navigating Toxic Masculinity in Clients as a Beginner Therapist. In B.C. King, T.A. Stewart (eds.): Cases in Cross-Cultural Counseling Strategies. Hershey: IGI Global.

Connell R.W. (1983): Which Way is Up? Essays on Sex, Class, and Culture. Crows Nest: Allen and Unwin.

Connell R.W. (1987): Gender and Power. Crows Nest: Allen and Unwin.

Connell R.W. (1992): A Very Straight Gay: Masculinity, Homosexual Experience, and the Dynamics of Gender. American Sociological Review v. 57, pp. 735-751.

Connell R.W. (1995/2005): Masculinities ( $2^{\text {nd }}$ ed.). Berkeley (CA): University of California Press.

Crete G.K., Singh A.A. (2015): Resilience Strategies of Male Survivors of Childhood Sexual Abuse and Their Female Partners: A Phenomenological Inquiry. Journal of Mental Health Counseling, v. 37, pp. 341-354.

Donaldson M., Howson R. (2009): Men, Migration and Hegemonic Masculinity. University of Wollongong Research Online (https://ro.uow.edu.au/artspapers/191; last access: 10.11.21).

El Feki S., Heilman B., Barker G. (2017): Understanding Masculinities: Results from the International Men and Gender Equality Survey (IMAGES) - Middle East and North Africa. Cairo and Washington D.C.: UN Women and Promundo-US.

Eriksson Baaz M., Stern M. (2013): Sexual Violence as a Weapon of War? Perceptions, Prescriptions, Problems in the Congo and Beyond. London: Zed Books.

Erikson E. H. (1994 (reissue): Identity and the Life Cycle. New York: W.W. Norton \& Company.

Forde C., Duvvury F. (2017): Sexual Violence, Masculinity, and the Journey of Recovery. Psychology of Men \& Masculinity, 18(4), pp. 301-310 (https://doi.org/10.1037/men00 00054; last access: 10.11.21).

Garbarino J. (2000): Lost Boys: Why Our Sons Turn Violent and How Can We Save Them. New York: Anchor Books.

Herz M. (2019): "Becoming” a possible Threat: Masculinity, Culture and Questioning among Unaccompanied Young Men in Sweden, Identities, 26(4), pp. 431-449 (https://doi.org/10.1080/ 1070289X.2018.1441692; last access: 10.11.21).

Hooks B. (2004): The will to change: Men, masculinity, and love. New York: Atria Books.

Iwamoto D.K., Brady J., Kaya A., Park A. (2018): Masculinity and Depression: A Longitudinal Investigation of Multidimensional Masculine Norms among College Men. American Journal of Men's Health, 12(6), pp. 1873-1881 (https://doi.org/10.1177/1557988318785549; last access: 10.11.21).

Joanna S.D., Cory K.C. (2018): The Secret Sorrows Of Men: Impact of Dynamic Interpersonal Therapy on "Masculine Depression". Psychoanalytic Psychotherapy, 32(2), pp. 181-196. (https://doi.org/10 .1080/02668734.2018.1458747; last access: 10.11.21).

Katz J.N. (1983): Gay/Lesbian Almanac: A New Documentary. Part II the Modern United States: The Invention of the Homosexual 1880-1950. New York: Harper \& Row.

Katz J.N. (1995): The Invention of Heterosexuality. New York: Dutton.

Kessler S.J., Ashenden D.J., Connell R.W., Dowsett G.W. (1982): Ockers and Disco-maniacs. Inner City: Inner City Education Center.

Kia-Keating M., Grossman F., Sorsoli F., Epstein M. (2005): Containing and Resisting Masculinity: Narratives of Renegotiation among Resilient Male Survivors of Childhood Sexual Abuse. Psychology of Men \& Masculinity, 6(3), pp. 169-185 (https://doi.org/10.1037/1524-9220.6.3.169; last access: 10.11.21).

Kimmel M. (1994). Masculinity as Homophobia: Fear, Shame, and Silence in the Construction of Gender Identity. In H. Brod, M. Kaufman (eds.): Theorizing Masculinities. New York: Sage, pp. 119-141).

Kirby R. (2019): The Perils of Toxic Masculinity: Four Case Studies. Trends in Urology and Men's Health, 10(5), pp. 18-20 (https://doi.org/10.1002/tre.712; last access: 10.11.21). 
Kupers T.A. (2005): Toxic Masculinity as a Barrier to Mental Health Treatment in Prison. Journal of Clinical Psychology, 61(6), pp. 713-724 (https://doi.org/10.1002/jclp.20105; last access: 10.11.21).

Kurassinska L. (2019, January 14): Men in Europe Must Stop Blaming Migrants For "Importing" Gender Violence. Open Democracy, n.d.

Lenders J. (2018, May10): The crisis of masculinities-A brief overview. Social Science Work. https:// socialscienceworks.org/the-crisis-of-masculinities-a-brief-overview/

Longfellow H.W. (1839): Hyperion. A Romance. New York: Samuel Colman.

Mahalik J.R., Good G.E., Englar-Carlson M. (2003): Masculinity Scripts, Presenting Concerns, And Help Seeking: Implications for Practice and Training. Professional Psychology, Research and Practice, 34(2), pp. 123-131 (https://doi.org/10.1037/0735-7028.34.2.123;last access: 10.11.21).

Marcus H. (2019): "Becoming" a Possible Threat: Masculinity, Culture and Questioning Among Unaccompanied Young Men in Sweden, Identities, 26(4), pp. 431-449. (https://doi.org/10.1080/10 70289X.2018.1441692; last access: 10.11.21).

Nagayama Hall G. (2017, March 13): What is Healthy Masculinity? Psychology Today (https://www. psychologytoday.com/au/blog/life-in-the-intersection/201703/what-is-healthy-masculinity; last access: 10.11 .21 ).

Nelson M. (2019): Traditional Gender Roles: The Culture of Toxic Masculinity and the Effect on Male Rape Victims (Item 71 - Master dissertation, Bridgewater State University). BSU Master's Theses and Projects (https://vc.bridgew.edu/theses/71; last access: 10.11.21).

Nhan T., (2018): Redefining Masculinity. Sociology Student Work Collection, v. 24 (https://digitalcommons.tacoma.uw.edu/gender_studies/24; last access: 10.11.21).

Olivius E. (2016): Refugee Men as Perpetrators, Allies or Troublemakers? Emerging Discourses on Men and Masculinities in Humanitarian Aid. Women's Studies International Forum, v. 56, pp. 56-65.

Petersson C.C., Plantin, L. (2019): Breaking with Norms of Masculinity: Men Making Sense of Their Experience of Sexual Assault. Clin Soc Work J, 47(4), pp. 372-383. (https://doi.org/10.1007/ s10615-019-00699-y; last access: 10.11.21).

Reeser T.W, Gottzén L. (2018): Masculinity and Affect: New Possibilities, New Agendas, Norma, 13(3-4), pp. 145-157 (https://doi.org/10.1080/18902138.2018.1528722; last access: 10.11.21).

Salter M. (2019, February 27). The Problem with a Fight against Toxic Masculinity. The Atlantic, n.d. (https://www.theatlantic.com/health/archive/2019/02/toxic-masculinity-history/583411; last access: 10.11 .21$)$.

Seidler V. (1989): Rediscovering Masculinity: Reason, Language, and Sexuality. London-New York: Routledge.

Sculos B.W. (2017): Who's Afraid of "Toxic Masculinity"? Class, Race and Corporate Power, 5(3), n.d. (http://digitalcommons.fiu.edu/classracecorporatepower/vol5/iss3/6; last access: 10.11.21).

Stretmo L. (2014): Governing the Unaccompanied Child. Media, Policy and Practice. University of Gothenburg.

Tajfel H., Turner J.C. (1979): An Integrative Theory of Intergroup Conflict. In S. Worchel, W.G. Austin (eds.): The Social Psychology of Intergroup Relations. Bonn: Brooks Cole Publ., pp. 33-47.

Waling A. (2019a): Problematizing "Toxic" and "Healthy” Masculinity for Addressing Gender Inequalities. Australian Feminist Studies, 34(101), pp. 362-375, https://doi.org/10.1080/08164649.2019.167 9021.

Waling A. (2019b): Rethinking Masculinity Studies: Feminism, Masculinity, and Post-Structural Accounts of Agency and Emotional Reflexivity. Journal of Men's Studies, 27(1), pp. 89-107, https:/ doi/10.1177/1060826518782980. 